Simposium I Jaringan Perguruan Tinggi untuk Pembangunan Infrastruktur Indonesia, 2016

\title{
Konsep Pemodelan Durasi dan Volume Parkir untuk Berbagai Tata Guna Lahan di Kota Surabaya
}

\author{
Anak Agung Gde Kartika ${ }^{a}$, Prof. Ir. Indrasurya B. Mochtar, M.Sc., Ph.D. ${ }^{\text {b }, ~ I r . ~ H e r a ~ W i d y a s t u t i, ~}$ \\ M.T., Ph.D
}

${ }^{a}$ Ph.D.Student of ITS, Jurusan T Sipil ITS, Surabaya 60111, Indonesia

${ }^{b}$ Lecturer of ITS, T Sipil ITS, Surabaya 60111, Indonesia

\begin{abstract}
Both parking fee and parking tax are the potential income for most local authorities in Indonesia since they are considered as the parts of of local authority's revenue (Pendapatan Asli Daerah, PAD). However, currently many local authorities including that in Surabaya has a problem in determining target as well as the achievement of annual parking revenue. This situation takes place due to the lack of reliable method to estimate the parking revenue including both parking fee and parking tax either on-street parking nor off-street parking. Meanwhile, there are growing investments of public and private facilities in many capital cities of both regency and provincy including apartments, hotels, malls, campus, hospitals, convention buildings, terminals, offices, restaurants and mixed uses in which many parking spaces will be provided to support their activities later on. The providing of new parking spaces will therefore potentially contribute to the local authorities's revenue as the consequnces. Main variable to contribute the parking revenue are the number of parked vehicle as well as the parking duration (when progressive fee is applied). Both number of parked vehicle and parking durations for several landuses will be modelled in this Dissertation so that they can be used as references for estimating the anual parking revenue of local authotities as the part of local authorities revenue (PAD). Moreover, these models will be useful for parking facilities investors to analyse the their financial investment.

Keyword: Parking, Off-street, Landuses, Local Government's Revenue (PAD), Surabaya
\end{abstract}

\section{Pendahuluan}

\subsection{Latar Belakang}

Penyediaan dan pembatasan parkir saat ini banyak dipakai sebagai instrumen pembatasan kendaraan [1-2]. Di sisi lain parkir merupakan salah satu sumber Pendapatan Asli Daerah yang cukup potensial, terlebih-lebih pada daerah yang memiliki tingkat kepemilikan kendaraan yang tinggi dan aktivitas ekonomi yang tinggi pula asalkan dapat dikelola dengan baik dan benar. Meskipun, dibandingkan dengan komponen kontributor pajak daerah, pajak pakir bukan merupakan yang terbesar pangsanya [3].

Namun demikian, sudah menjadi rahasia umum bahwa pengelolaan parkir di daerah-daerah di Indonesia, baik parkir tepi jalan maupun luar jalan, termasuk Jakarta sebagai Ibukota Negara Indonesia selalu dicirikan dengan pendapatan yang bocor karena ketiadaan system yang dapat memprediksi berapa sebetulnya potensi pendapatan yang bisa dikumpulkan. Demikian juga halnya yang terjadi di Surabaya sebagai ibukota Propinsi Jawa Timur memiliki target pemasukan sektor parkir sebesar Rp. 80M sementara pada tahun 2014 realisasi pendapatan parkir hanya sekitar 48M atau sekitar 60\% [4]. Hal ini sudah berlangsung cukup lama terbukti [5], prosentase realisasi pendapatan parkir tepi jalan pada Tahun 2009 dan 2010 adalah $65.57 \%$ dan 51.73\%. Sementara itu, disebutkan bahwa kebocoran pendapatan parkir surabaya mencapai 40\%[6]. Bahkan selama kurun waktu 20082011 realisasi pendapatan pajak parkir total selalu di bawah target yang ditetapkan[3].

Ketiadaan sistem yang dapat memprediksi berapa potensi pendatapan dikarenakan beberapa alasan: pertama, belum tercatatnya semua volume parkir yang sesungguhnya, kedua, adanya perbedaan antara besarnya tarif resmi dan tarif yang dipungut di lapangan, ketiga, adanya sistem pentarifan parkir yang non-konvensional (progresif) yang menyebabkan kinerja perparkiran (durasi parkir) sangat berperan dalam memperoleh pendapatan parkir tersebut, keempat belum pernah ada panduan terkait pemungutan pajak parkir dikaitkan dengan kinerja parkir baik off-street maupun on-street, kelima, adanya variasi landuse yang dapat mempengaruhi karakteristik parkir yang ujungnya dapat mempengaruhi pendapatan parkir yang sebenarnya, keenam banyaknya titik parkir yang tersebar di wilayah perkotaan yang belum terdaftar dalam database titik parkir pemerintah akibat adanya investasi fasilitas gedung baru di suatu daerah dan ketujuh adanya fasilitas yang semestinya memilki parkir tak berbayar (gratis) ternyata di lapangan memungut biaya parkir (berbayar) seperti halnya terjadi di gedung pemerintah, BUMN dan Gedung swasta lainnya. Makalah ini akan mengusulkan konsep pemodelan volume dan durasi parkir kendaraan pada landuse-landuse yang ada di perkotaan sehingga dapat dipakai untuk memprediksi besarnya pendapatan yang bisa diperoleh oleh Pemerintah Daerah.

Dengan adanya sistem pemungutan tarif parkir dan pajak parkir diharapkan dapat membuat para investor di bidang operator parkir bisa membuat perencanaan investasinya mengingat sumber pemasukannnya akan dapat diprediksi dengan lebih akurat. Selain itu pemerintah juga dapat mengurangi besarnya kebocoran pajak parkir yang diterima sebagai PAD yang otomatis dapat

\footnotetext{
* Corresponding author. Tel.: +852-1000-1272; fax: +31-5947284.

E-mail address: kartika@ce.its.ac.id, a.agung.kartika@gmail.com
} 
meningkatkan pemasukan pemerintah untuk membiayai pembangunan di wilayah pemerintah kota atau kabupaten yang bersangkutan. Keseluruhan konsep kerangka berpikir makalah iniditunjukkan pada Gambar 1Files must be in MS Word only and should be formatted for direct printing. Figures and tables should be embedded and not supplied separately.

\subsection{Perumusan Masalah}

Dari uraian di atas permasalahan yang dapat dirumuskan dalam makalah ini adalah: Bagaimana konsep pemodelan volume dan durasi parkir kendaraan-kendaraan yang berada di beberapa landuse (Hotel, Apartemen, Mall/Pusat perbelanjaan, Kampus, Rumah sakit, Terminal/Stasiun, Restoran, Tempat Konvensi, Perkantoran/Bank, Campuran) dikaitkan dengan kinerja parkir lainnya seperti turnover, akumulasi, indeks dan kapasitas dinamis serta dengan karakteristik operasional (jam operasi) dan varibel fisik lainnya (jumlah SRP dan luas gedung)

\section{Kajian Pustaka}

Saat ini penelitian tentang parkir termasuk di dunia, termasuk di Indonesia banyak didominasi tentang kebutuhan dan kinerja parkir yang diperlukan pada landuse-landuse tertentu yang memodelkan kebutuhan ruang parkir pada pusat perbelanjaan di Denpasar Bali beserta karakteristik parkirnya[7]. Sementara untuk dilakukan juga analisis kebutuhan ruang parkir di area kampus Universitas Pontianak[8]. Anggraini, Burhanuddin dan Ilyas (2013) salah satu lokasi di Banda Aceh juga menganalisis kebutuhan ruang parkir dan kinerja jalan. Demikian pula untuk membahas tentang kinerja park and ride pada terminal LRT Terminal Putra Jaya dan Stasiun Kelana Jaya Malaysia[9].

Namun demikian ada beberapa penelitian yang sedikit menyinggung tentang potensi pendapatan parkir sebagaimana yang dilakukan dengan mendiskusikan tentang potensi pendapatan PAD Kota Surabaya[10] dari parkir tepi jalan serta beberapa yang mendiskusikan tentang potensi PAD Kabupaten Hulu Sungai Tengah dari parkir tepi jalan dan parkir luar jalan (yang diperoleh dari pasar)[11], namun keduanya belum memasukkan aspek pemodelan dan variasi pendapatan jika terjadi perubahan tarif dan untuk parkir di luar badan jalan belum membedakan macam-macam landuse yang ada. Sementara itu pendapatan parkir akan sangat tergantung pada banyaknya kendaraan (volume) yang parkir dan durasi parkir jika tarif progresif akan diterapkan. Untuk itu perlu dimodelkan besarnya kedua variabel di atas agar pendapatan dari parkir dapat diketahui. Berikut ringkasan topik penelitian tentang parkir yang berhasil dirangkum.

\subsection{Parkir Sebagai Instrumen Pembatasan Demand}

Kebutuhan ruang parkir biasanya didesain berdasarkan kebutuhan terhadap fasilitas parkir itu sendiri, kebutuhan ruang parkir dihitung berdasarkan variabel-variebel tertentu tergantung tipe land usenya. Paradigma baru penyediaan parkir memposisikan fasilitas parkir sebagai instrumen pembatasan pemanfaatan kendaraan di banyak negara-negara maju di dunia. Artinya keberadaan fasilitas parkir cenderung dibatasi dengan maksud untuk mengurangi penggunaan kendaraan pribadi, namun tentunya pembatasan ini tidak bisa berjalan sendiri, namun membutuhkan sinergi dengan penyediaan sarana alternatif transportasi diantaranya angkutan umum massal yang memadai [2]. Di banyak negara maju pendekatan ini menyebabkan penggunaan kendaraan pribadi dapat berkurang secara signifikan[1].

Pemerintah daerah setempat[2] membuat kebijakan yang memfokuskan pada upaya mempersingkat durasi parkir serta penyebaran penggunaaan parkir supaya tidak terfokus pada jam puncak tertentu sehingga distribusinya lebih merata.

Prinsip-prinsip yang diterapkan dalam pembatasan ini adalah:

1. Pricing policy yang konsisten untuk mendukung aktivitas kunjungan ke CBD, menggalakkan penggunaan angkutan umum, menghambat perjalanan pada jam sibuk dan mengurangi kemacetan

2. Prioritas parkir durasi pendek

3. Dalam menentukan tarif parkir akan menggunakan pendekatan yng konsisten, sederhana, berdasar hukum, tranparan dan berbasis data

4. Menggunakan demand-responsive pricing dan mengenakan tarif serendah mungkin untuk mencapai target okupansi.

5. Menjamin kebutuhan parkir saat jam puncak dengan durasi pendek dapat dilayani sebisa mungkin.

6. Diskon tarif untuk pada jam tidak sibuk untuk mengurangi perjalanan saat jam puncak dan mengurangi kemacetan.

7. Melakukan manajemen parkir khusus saat ada event khusus seperti liburan sekolah. 


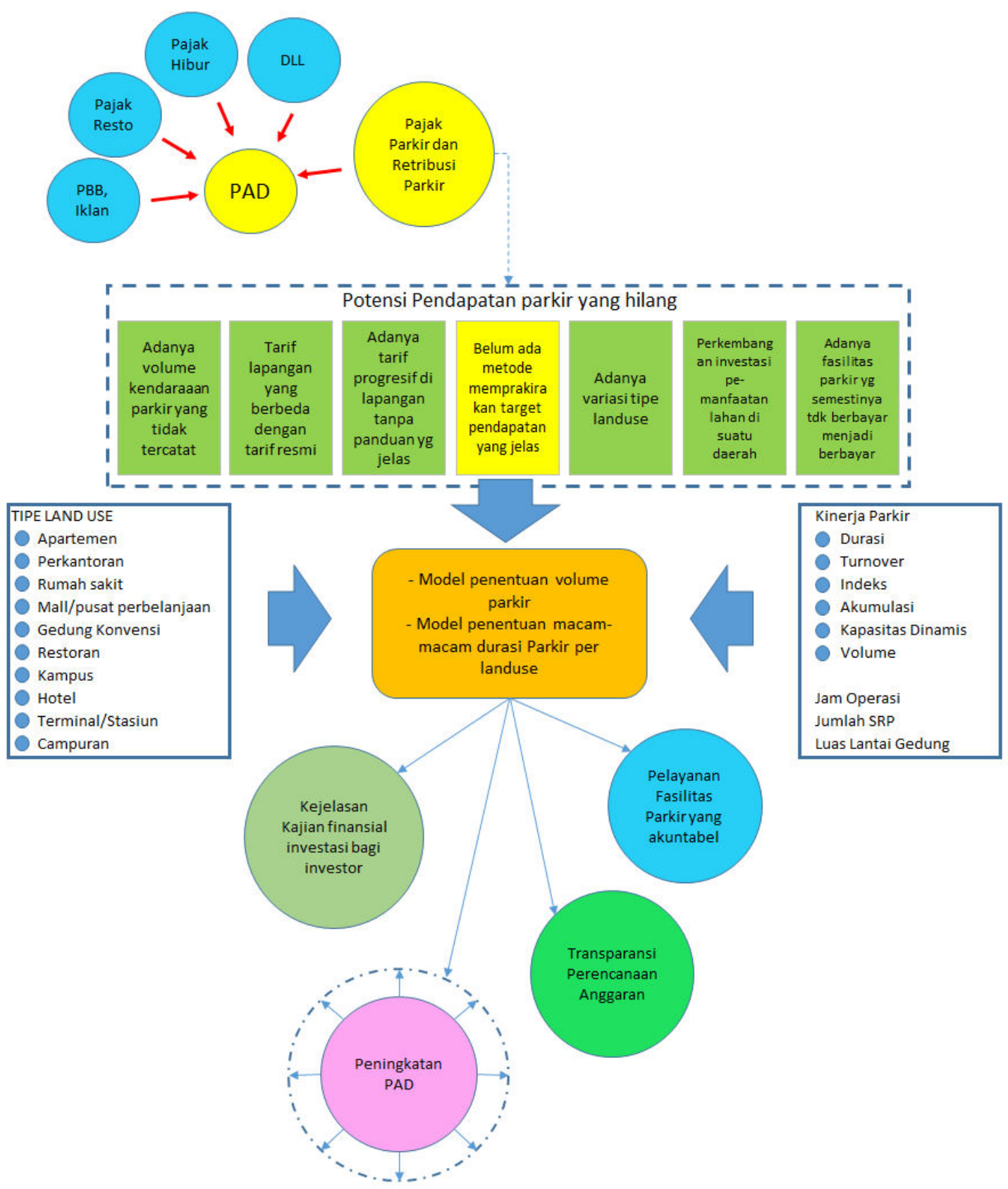

Gambar 1. Konsep Kerangka Berpikir

\subsection{Perilaku Konsumen Parkir}

Penelitian tentang probabilitas pemilihan lokasi parkir pengendara sepeda motor di Kota Surabaya dengan tiga opsi yang meliputi on-street parking, parkir garage parking atau lot parking. Penelitian ini menggunakan metode regresi logit multinomial dalam penentuan modelnya. Hasil penelitiannya adalah sebagai berikut[12]:

$$
\begin{aligned}
& P_{(\text {lot parking })}=\frac{1}{1+e^{-1.082 \times 1-2.185 \times 2+1.393 \times 3+0.449 \times 4}+e^{-0.228 \times 1-1.215 \times 2+1.160 \times 3+0.002 \times 4}} \ldots
\end{aligned}
$$

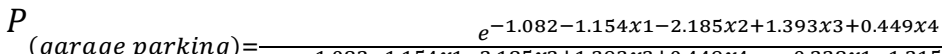

$$
\begin{aligned}
& \text { (garage parking })=\frac{e^{-1.082-1.154 \times 1-2.152-1.154 \times 1-2.185 \times 2+1.393 \times 3+0.449 \times 4}+e^{-0.228 \times 1-1.215 \times 2+1.160 \times 3+0.002 \times 4}}{1+e^{-1.082}}
\end{aligned}
$$

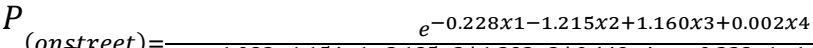

$$
\begin{aligned}
& \text { onstreet) }=\frac{e^{-0.228 x 1-1.215 x 2+1.160 x 3+0.002 \times 4}}{+e^{-1.082-1.154 \times 1-2.185 \times 2+1.393 \times 3+0.449 \times 4}+e^{-0.228 \times 1-1.215 \times 2+1.160 \times 3+0.002 \times 4}}
\end{aligned}
$$

$\mathrm{X} 1=$ availability on street parking,

$\mathrm{X} 2$ = availability lot parking, 
$\mathrm{X} 3$ = parking time in afternoon, and

$\mathrm{X} 4$ = income

\subsection{Kajian kinerja dan kebutuhan fasilitas parkir}

Banyak penelitan yang berkisar tentang pembahasan kebutuhan fasilitas parkir (jumlah SRP) dan kinerja teknisnya (durasi, volume, kapasitas, indeks parkir, turnover, dan kapasitas dinamis) dengan obyek lokasi yang berbeda, diantaranya: lokasi pusat perbelanjaan di Surabaya[13], lokasi pusat perbelanjaan di Denpasar[7], Khalid U. A. dan lokasi stasiun LRT di Malaysia[9], lokasi kampus politeknik di Pontianak[8], lokasi pusat perbelanjaan di Jember[14].

\subsection{Aspek ekonomi dan Finansial Fasilitas Parkir}

Penelitian aspek finansial terkait potensi pendapatan parkir tepi jalan di Kota Surabaya dilakukan oleh Memodelkan potensi pendapatan parkir dengan hasil model sebagai berikut[10]:

$$
\begin{aligned}
& Y=1746232 x \text { (jika tarif sesuai Perda 1/2009) } \\
& Y=2608238 x \text { (jika tarif sesuai kondisi lapangan) } \\
& Y=2807819 x \text { (jika tarif progresif) }
\end{aligned}
$$

Dimana:

$$
\begin{aligned}
& \mathrm{Y} \text { : potensi pendapatan per tahun }(\mathrm{Rp} / \mathrm{th}) \\
& \mathrm{X} \text { : panjang titik parkir }
\end{aligned}
$$

Selain itu melakukan kajian tentang selisih pendapatan parkir luar jalan pada landuse tipe pasar di Kabupaten Hulu Sungai Tengah Kalimantan Selatan[11]. Sementara dibahas juga tentang kesediaan mahasiswa membayar tarif parkir di kampusnya[15]. Sampel diambil dari penggguna mobil dan sepeda motor di kampus Unika Parahyangan. Atribut yang dipertimbangkan dalam analisis meliputi durasi parkir dan kelengkapan fasilitas parkir.

Sementara itu penentuan lokasi pembangunan fasilitas parkir bandara yang letaknya relatif terpisah dari bandara di Italia[16]. Sebagaimana diketahui bahwa semakin jauh dari bandara maka semakin sedikit calon penumpang pesawat mau menggunakan fasilitas parkir tersebut. Padahal di sisi lain penyediaan fasilitas parkir yang jauh dari bandara memiliki keuntungan diantaranya harga lahan yang relatif murah dan relatif terhindar dari kemacetan walaupun harus ada konsekuensi untuk menyediakan kendaraan penghubung dari dan menuju terminal bandara itu sendiri dimana dalam kasus ini akan disediakan shuttle bus dengan tarif tertentu yang dimasukkan dalam ongkos tarif parkir kendaraan.

Penentuan lokasi berdasarkan trade-off antara demand dan operasional cost penyediaan tempat parkir termasuk penyediaan shuttle bus-nya. Metode analisisnya dilakukan dengan cara optimalisasi antara penyediaan SRP, tarif parkir dan operasional parkir (biaya pencarian tempat parkir, penyediaan shuttle dengan headway dan kapasitas tertentu dan faktor utilisasi).

Perspektif yang berbeda terkait perparkiran dimana pada penelitiannya dibahas tentang kontribusi dan efektivitas pajak daerah sebagai sumber PAD, sementara Pajak Parkir merupakan salah satu pajak yang dapat dipungut oleh daerah sebagai sumber PAD [3].

Kriteria tingkat kontribusi diukur dari standar yang dikeluarkan oleh Tim Litbang Depdagri-Fisipol UGM (1991) dalam Sari (2011)[3], sementara tingkat efektivitasnya diukur berdasarkan standar yang dikeluarkan oleh Kepmendagri No. 690.900-327 Tahun 1996 dalam Dwirandra (2008)[3].

\subsection{Pemanfaat Teknologi dalam Pelayanan dan Pengoperasian Fasilitas Parkir}

Beberapa peneltian terkait pemanfaatan teknologi dalam pengoperasian fasilitas parkir diantaranya membahas tentang pengaruh layout parkir dan perilaku pengemudi terhadap posisi alat pengisian ulang batere untuk mobil listrik nirkabel[17]. Hasilnya menunjukkan bahwa posisi parkir secara lateral memiliki akurasi yang lebih baik dibandingkan dengan posisi parkir secara longitudinal. Namun secara keseluruhan, hanya 5\% kendaraan yang secara akurat dapat berada pada posisi yang tepat untuk dapat diisi ulang baterenya.

Selain itu meneliti tentang aplikasi berbasis android untuk pencarian ruang parkir serta informasi tarif yang berlaku pada saat itu[18]. Pencarian berdasarkan slot allocation method sedangkan penarikan/pembayaran biaya parkir menggunakan RFID (Radio Frequency Identification Device). Dalam aplikasi ini juga dimungkinkan melakukan pembookingan terhadap ruang parkir yang tersedia berdasarkan lokasi yang terdekat dan termurah.

Sementara itu dengan memodelkan ketersediaan ruang parkir di kota kecil yang dalam hal ini Kota Mauritius, dalam penelitian juga dikembangkan juga software yang dapat diaplikasikan pada telepon selular sehingga pengemudi dapat mengetahui ruang parkir yang mungkin tersedia[19]. 


\subsection{Parkir dari Sisi Teknis}

Kinerja teknis perparkiran terdiri dari[20]:

1. Akumulasi Parkir yang didefinisikan sebagai jumlah kendaraan yang

2. Volume Parkir yang didefinisikan sebagai jumlah kendaraan yang parkir dalam rentang waktu tertentu. Volume dihitung dengan formula sebagai berikut:

3. Turnover Parkir (Tingkat penggantian) didefinisikan sebagai Tingkat penggunaan SRP, yang diperoleh dengan membandingkan volume parkir dan jumlah SRP yang tersedia atau dengan formula sebagai berikut:

4. Indeks Parkir atau okupansi parkir didefinisikan sebagai tingkat penggunaan SRP yang didapatkan dengan cara membandingkan Akumulasi parkir maksimum dengan SRP yang tersedia, yaitu:

5. Durasi Parkir didefinisikan sebagai lama waktu kendaraan saat memanfaatkan ruang parkir yang tersedia.

6. Kapasitas Dinamis, merupakan ukuran kapasitas dari ruang parkir yang merupakan fungsi dari waktu layan dan durasi parker.

\subsection{Parkir Menurut Perudangan-undangan di Indonesia}

A. UULAJ No. 22 Tahun 2009

Aturan-aturan dasar mengenai perparkiran diantaranya bahwa penyediaan ruang parkir untuk umum hanya disediakan pada Ruang Milik Jalan (Rumija) sesuai dengan ijin yang diberikan. Selain itu diatur juga tentang pemberian hak pengusahaan parkir oleh perorangan ataupun badan usaha baik yang badan usaha khusus parkir atau sebagai penunjang usaha pokok [21].

Penyelenggaraan parkir dalam Rumija diperbolehkan pada jalan kabupaten, jalan desa dan jalan kota sementara pada jalan propinsi dan jalan nasional tidak dinyatakan secara eksplisit diijinkan atau pelarangannnya

\section{B. $\quad$ Perwali Surabaya No. 37 Tahun 2015 tentang Perubahan Tarif Retribusi Tempat Khusus Parkir}

Perubahan tentang tarif Parkir tempat khusus parkir di Kota Surabaya diatur dalam Perwali No. 37 tahun 2015 dengan ringkasan sebagaimana Tabel 1 [22].

\section{Konsep Analisis}

\subsection{Potensi Pendapatan Parkir}

Analisis potensi pendapatan dilakukan dengan dua asumsi dasar yaitu berdasarkan tarif yang berlaku secara resmi dan berdasarkan tarif yang berlaku di lapangan tanpa kemungkinan adanya penerapan tarif progresif. Jumlah titik parkir yang ditinjau sesuai dengan jumlah titik parkir yang terdaftar di Dinas Perhubungan/Dinas Pendapatan Daerah Kota Surabaya.

Dari analisis di atas akan diperoleh selisih atau perbedaan antara pendapatan pajak parkir yang diterima oleh Pemkot Surabaya dengan yang seharusnya diterima jika tanpa penerapan tarif progresif. Variabel yang diperlukan untuk perhitungan ini adalah volume kendaraan parkir dan tarif parkir yang berlaku di Perda No 9/2012 dan yang berlaku di lapangan. Secara umum perhitungan pendapatan akan menggunakan formula berikut:

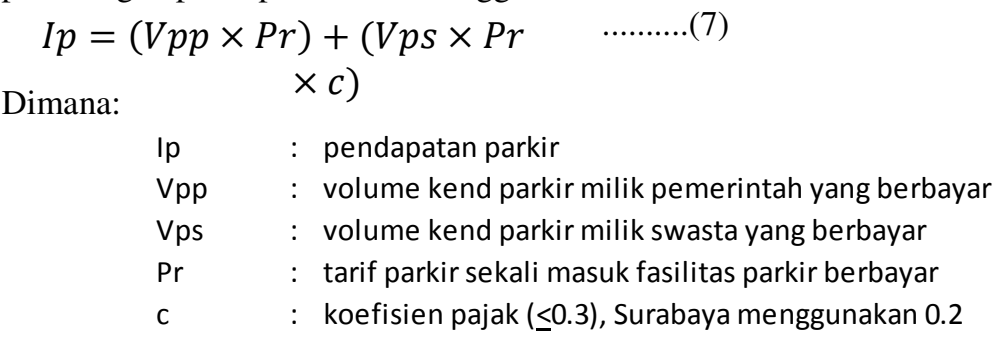

\subsection{Kinerja Parkir Landuse yang Ditinjau}

Analisis kinerja parkir dilakukan untuk semua tipe landuse yang ditinjau diantaranya: mall, perkantoran, apartemen, ruko, hotel, restoran, rumah sakit, terminal/stasiun, tempat konvensi. Kinerja yang diukur meliputi: akumulai parkir, jumlah parkir, turnover parkir, indeks parkir, dan durasi parkir. Analisis dilakukan untuk dua kondisi waktu, yaitu hari kerja (weekday) dan hari libur (weekend) sesuai dengan data yang diperoleh. 
Tabel 1. Tarif Retribusi Tempat Khusus Parkir

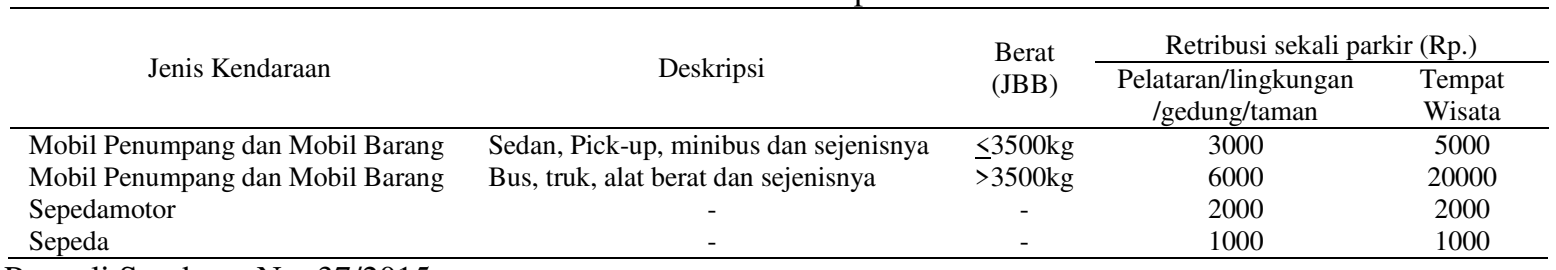

Sumber: Perwali Surabaya No. 37/2015

Pada Perda ini belum diatur besaran tarif progresif serta macam-macam skenario yang mungkin dapat diterapkan. Dalam hal penyelenggaraan parkir dilakukan oleh swasta secara komersial, pemerintah sesuai UU 28/2009 tentang Pajak Daerah dapat menarik pajak parkir maksimal sebesar 30\% dari tarif yang dipungut [23]dan diperjelas dengan Perda 4/2011 Kota Surabaya tentang Pajak Daerah yang menyatakan bahwa Pemerintah Kota Surabaya berhak menarik pajak parkir sebesar 20\% dari pendapatan yang diterima penyelengara parkir khusus [24].

\subsection{Potensi Pendapatan Parkir dengan Skenario Tarif Progresif dan Sesuai Tarif Lapangan}

Analisis potensi pendapatan parkir di sini akan melibatkan tarif progresif dimana untuk menghitungnya diperlukan kinerja parkir yang berupa durasi parkir sebagai inputnya selain volume parkir.

Istilah tarif parkir progresif diadopsi dari istilah perpajakan, terdapat tiga macam pengenaan tarif pajak progresif, yaitu[25]:

1. Progresif progresif: presentase kenaikan semakin membesar

2. Progresif tetap: presentase kenaikan tetap

3. Progresif degresif: presentase kenaikan semakin mengecil

Dalam tarif parkir progresif di Surabaya umumnya mengacu pada progresif tetap artinya ada kenaikan yang nilainya sama untuk setiap jam kelebihan parkir. Penggolongan tarif progresif yang dipakai di sini adalah sebagai berikut: $<5$ menit, $5-120$ menit, 2-3 jam, 3-4 jam, 4-5 jam, 5-6 jam, 6-7jam, >7 jam (parkir nginap)

Adanya durasi $<5$ menit dimaksudkan untuk mengakomodasi ketentuan free parking fee (biasanya pada pusat perbelanjaan) jika kendaraan berada di areal parkir selama kurang dari 5 menit. Biasanya ini dimanfaatkan oleh pengguna untuk menjemput dan mengantarkan pengunjung. Angka 5 menit ini akan dicek validasi-nya untuk jenis landuse-landuse yang lain. Semakin lama durasi free-parking fee nya tentunya akan mempengaruhi pendapatan parkirnya.

Pendapatan parkirnya nya secara umum akan dihitung dengan formula berikut:

$$
I p=\sum_{i=1}^{n} V p p_{i} \times P r_{i}+\left(\sum_{i=1}^{n} V p s_{j} \times P r_{j}\right) \times c
$$

Dimana:

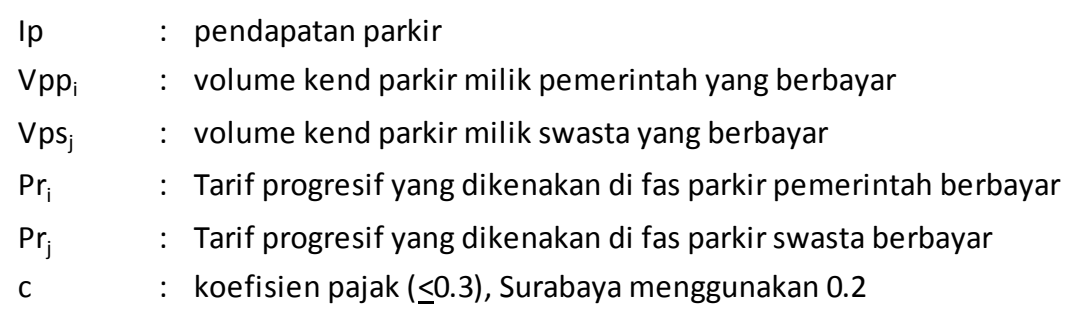


Tabel 2. Ringkasan Tinjauan Pustaka Penelitian Tentang Parkir

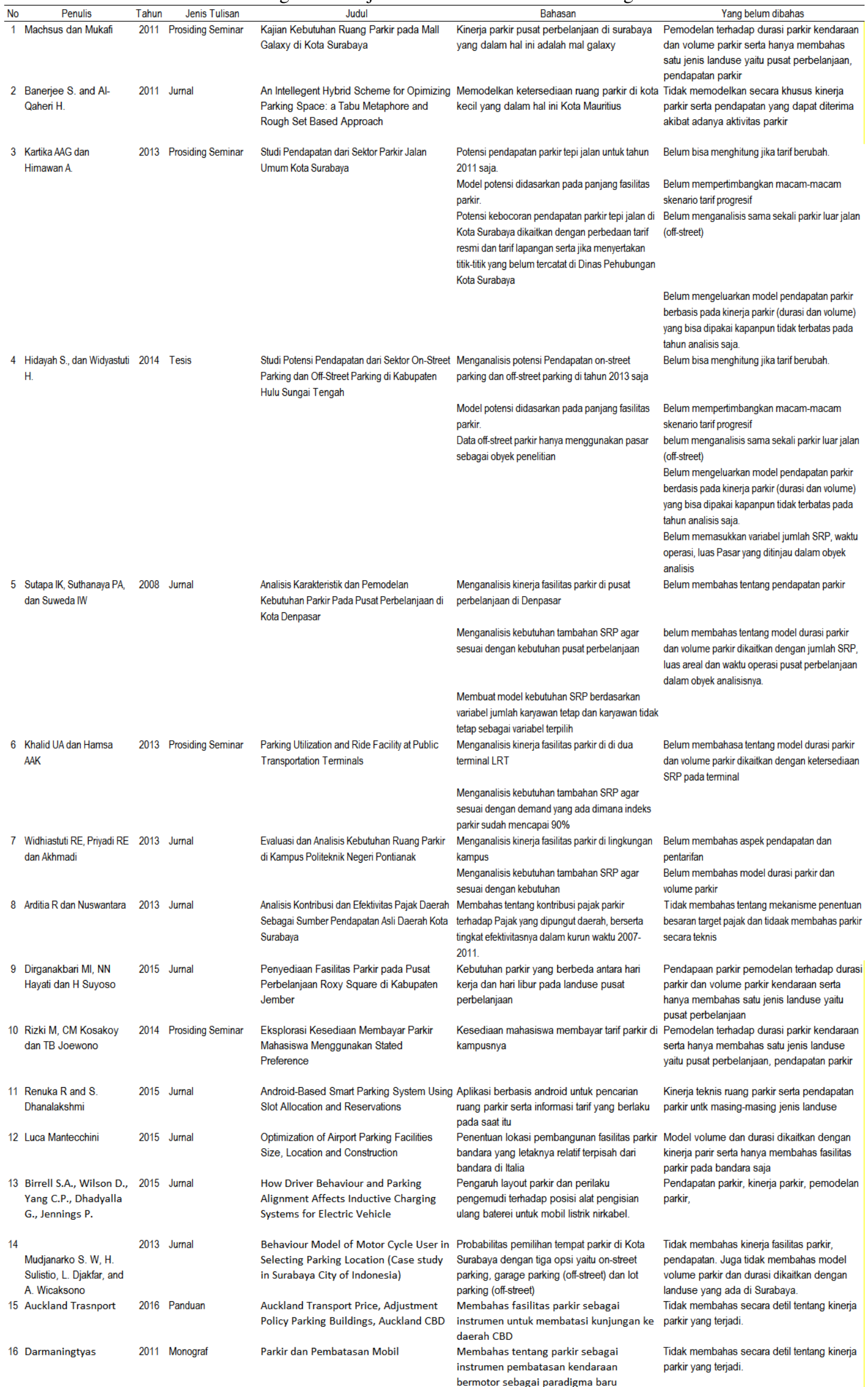




\subsection{Model Kinerja Parkir (Durasi, Volume) Setiap Landuse}

Sebagaimana dijelaskan sebelumnya, bahwa besarnya pendapatan retribusi parkir dan pajak parkir akan ditentukan oleh dua variabel teknis utama dan tarif parkir yang berlaku. Kedua variabel teknis tersebut adalah volume parkir dan durasi parkir. Untuk kedua variabel tersebut akan dicari dan dijadikan sebagai variabel terikat, sementara variabel bebasnya terdiri dari SRP, luas lantai, jam operasi, turnover, indeks dan durasi. Tabel 3 menunjukkan macam-macam variabel bebas dan variabel terikat yang akan dianalis. Sementara itu tarif ditetapkan melalui mekanisme Peraturan Daerah. Regresi yang dipakai adalah Regresi Komponen Utama (Principal Component Regression).

Tabel 3 Variabel Bebas dan Terikat Model.

\begin{tabular}{|c|c|c|c|}
\hline \multicolumn{2}{|c|}{ Vaiabel Terikat, Yi } & \multicolumn{2}{|c|}{ Variabel Bebas, Xi } \\
\hline \multirow[t]{8}{*}{ Volume parkir } & \multirow[t]{8}{*}{$\mathrm{Y}$} & Turnover & $\mathrm{X} 1$ \\
\hline & & Indeks & $\times 2$ \\
\hline & & Kapasitas Dinamis & $\mathrm{x} 3$ \\
\hline & & \begin{tabular}{|l|} 
Durasi rata-rata \\
\end{tabular} & $\mathrm{X} 4$ \\
\hline & & Akumulasi & $\times 5$ \\
\hline & & SRP Tersedia & $\times 6$ \\
\hline & & Jam Operasi & $\mathrm{X7}$ \\
\hline & & Luas Lantai & $\mathrm{x} 8$ \\
\hline \multicolumn{2}{|c|}{\begin{tabular}{|l} 
Durasi (\%Durasi tertentu) \\
\end{tabular}} & & \\
\hline$<5$ menit & Y1 & Turnover & $\mathrm{x} 1$ \\
\hline 5-120 menit & $\mathrm{Y} 2$ & Indeks & $\times 2$ \\
\hline 2-3 jam & Y3 & Kapasitas Dinamis & $\mathrm{X3}$ \\
\hline 3-4 jam & Y4 & Volume & $\mathrm{X} 4$ \\
\hline 4-5 jam & Y5 & Akumulasi & $\times 5$ \\
\hline 5-6 jam & Y6 & SRP Tersedia & $\times 6$ \\
\hline 6-7 jam & $\mathrm{Y7}$ & Jam Operasi & $\mathrm{X7}$ \\
\hline 7-8 jam & Y8 & Luas Lantai & $\mathrm{x} 8$ \\
\hline 8-9 jam & Y9 & & \\
\hline
\end{tabular}

Model akan dibuat untuk setiap landuse yang dianalis dengan dua kondisi operasi yaitu hari kerja dan hari libur. Variabelvariabel bebas yang tercetak tebal di atas merupakan variabel fisik dan operasi yang sangat mudah diperoleh dan selalu terdapat dalam setiap fasilitas parkir, sementara variabel lainnya merupakan variabel yang tergantung pada jenis landusenya dan akan dapat diganti dengan hasil model untuk setiap landuse yang akan dibahas.

\section{DAFTAR PUSTAKA}

[1] Darmaningtyas, "Parkir dan Pembatasan Mobil," 2011. .

[2] Auckland Transport Price, "AT-Off-Street-Parking-Price-Policy," 2016. [Online]. Available: https://at.govt.nz/media/359818/AT-Off-Street-Parking-Price-Policy.pdf.

[3] R. Arditia and D. A. Nuswantara, "Analisis Kontribusi dan Efektivitas Pajak Daerah Sebagai Sumber Pendapatan Asli Daerah Kota Surabaya," 2013.

[4] Suarasurabaya.net (Kelana Kota), “DPRD Surabaya Soroti Kenaikan Tarif Parkir Mal,” 2015.

[5] Berita Surya, "Pendapatan Parkir Rendah, Digemol Jukir Nakal," 2012.

[6] Hakim, "Kebocoran Pendapatan Parkir di Surabaya Capai 40\%," Sindonews, 2014.

[7] I. K. Sutapa, P. A. Suthanaya, and I. Suweda Wayan, "ANALISIS KARAKTERISTIK DAN PEMODELAN KEBUTUHAN PARKIR PADA PUSAT PERBELANJAAN DI KOTA DENPASAR | Jurnal Ilmiah Teknik Sipil,” J. Ilm. Tek. Sipil, vol. 12, no. 2, pp. 165-186, 2008.

[8] R. Widhiastuti, E. Priyadi, and Akhmadali, "EVALUASI DAN ANALISIS KEBUTUHAN RUANG PARKIR DI KAMPUS POLITEKNIK NEGERI PONTIANAK,” J. Tek. Sipil UNTAN, vol. 13, no. 1, pp. 161-175, 2013.

[9] K. U.A. and A. A. K. Hamsa, "Parking Utilization and Ride Facility at Public Transportation Terminals," in Proceedings of the Eastern Asia Society for Transportation Studies, EASTS, 2013.

[10] A. A. G. Kartika and H. A, "Studi Pendapatan dari Sektor Parkir Jalan Umum Kota Surabaya," in Seminar Nasional IX2013 Teknik Sipil ITS Surabaya, 2013.

[11] S. Hidayah and H. Widyastuti, "Studi Potensi Pendapatan dari Sektor On-Street Parking dan Off-Street Parking di Kabupaten Hulu Sungai Tengah, Tesis Bidang Studi Manajemen Rekayasa Tranportasi,” Institut Teknologi Sepuluh Nopember Surabaya, 2014.

[12] S. Wiwoho Mudjanarko, H. Sulistio, L. Djakfar, and A. Wicaksono, "Behaviour Model of Motor Cycle User in Selecting Parking Location (Case study in Surabaya City of Indonesia)," J. Basic. Appl. Sci. Res, vol. 3, no. 7, pp. 842-846, 2013.

[13] Machsus and Mukafi, "KAJIAN KEBUTUHAN RUANG PARKIR PADA MALL GALAXY DI KOTA SURABAYA," in Seminar Nasional Aplikasi Teknologi Prasarana Wilayah 2011, 2011, pp. 133-139. 
[14] M. I. Dirganakbari, N. N. Hayati, and H. Suyoso, "PENYEDIAAN FASILITAS PARKIR DI PUSAT PERBELANJAAN ROXY SQUARE KABUPATEN JEMBER,” J. Transp., vol. 15, no. 1, 2015.

[15] M. Rizki, C. Kosakoy, and T. Joewono, "Eksplorasi Kesediaan Membayar Parkir Mahasiswa Menggunakan Stated Preference Prosiding FSTPT 17,” in International Symposium, 2014.

[16] L. Mantecchini, "OPTIMIZATION OF AIRPORT PARKING FACILITIES SIZE, LOCATION AND CONNECTION," ARPN J. Eng. Appl. Sci., vol. 10, no. 2, pp. 754-758, 2015.

[17] S. A. Birrell, D. Wilson, C. Pin Yang, G. Dhadyalla, and P. Jennings, "How driver behaviour and parking alignment affects inductive charging systems for electric vehicles," 2015.

[18] R. R and D. S, “ANDROID BASED SMART PARKING SYSTEM USING SLOT ALLOCATION \& RESERVATIONS,” ARPN J. Eng. Appl. Sci., vol. 10, no. 7, pp. 3116-3120, 2015.

[19] B. Soumya and H. Al-Qaheri, "An intelligent hybrid scheme for optimizing parking space: A Tabu metaphor and rough set based approach," Egypt. Informatics J., vol. 12, no. 1, pp. 9-17, Mar. 2011.

[20] F. D. (Frederick D. Hobbs, Traffic Planning and Engineering, 2nd Edition. Pergamon Press, 1979.

[21] MPR Republik Indonesia, "Undang-Undang Republik Indonesia No. 14 Tahun 2009 tentang Lalu Lintas dan Angkutan Jalan," 2009.

[22] Pemkot Surabaya, "Peraturan Walikota Surabaya No.37 Tahun 2015 Tentang Perubahan Tarif Retribusi Tempat Khusus Parkir.," 2015.

[23] P. R. Indonesia, "Undang-Undang Republik Indonesis No. 28 Tahun 2009."

[24] Pemkot Surabaya, "Peraturan Daerah Pemerintah Kota Surabaya No. 4 Tahun 2011 tentang Pajak Daerah."

[25] Mardiasmo, Perpajakan. Yogyakarta: Andi, 2009.

Arditia R. dan Nuswantara D.A. (2013) Analisis Kontribusi dan Efektivitas Pajak Daerah Sebagai Sumber Pendapatan Asli Daerah Kota Surabaya, e-journal dipublikasikan oleh Alim Sumarno 17 Mei 2013, retrieved from http://id.scribd.com/doc/141986298/ANALISIS-KONTRIBUSI-DAN-EFEKTIVITAS-PAJAK-DAERAH-SEBAGAISUMBER-PENDAPATAN-ASLI-DAERAHKOTA-SURABAYA\#scribd, retrieved in 18 Mei 2015.

AT (2016) Auckland Transport Price, Adjustment Policy Parking Buildings, Auckland CBD, Auckland Transport, https://at.govt.nz/media/359818/AT-Off-Street-Parking-Price-Policy.pdf, diunduh pada tanggal 15 Mei 2016.

Banerjee S. and Al-Qaheri H. (2011) An Intellegent Hybrid Scheme for Opimizing Parking Space: a Tabu Metaphore and Rough Set Based Approach, Egyptian Informatics Journal 12, 9-17, Cairo University.

Beritasurya (2012) Pendapatan Parkir Rendah, Digemol Jukir Nakal, 02-02-2012, retrieved from http://beritasurabaya.net/index_sub.php?category=4\&id=5366, retrieved in 3 april 2015.

Birrell S.A., Wilson D., Yang C.P., Dhadyalla G., Jennings P. (2015) How Driver Behaviour and Parking Alignment Affects Inductive Charging Systems for Electric Vehicle. Elsevier Journal, Transportation Research Part C.

Darmaningtyas (2011) Parkir dan Pembatasan Mobil, diunduh pada tanggal 5 Maret 2016 .http://sriwiwoho.blogspot.co.id/2011/03/parkir-dan-pembatasan-mobil.html

Dirganakbari MI, NN Hayati dan H Suyoso (2015) Penyediaan Fasilitas Parkir pada Pusat Perbelanjaan Roxy Square di Kabupaten Jember. Jurnal Transportasi, FSTPT, Vol 15, No 1.

Draper, N.R dan Smith, H.( 1992) Analisis Regresi Terapan, edisi kedua. Alih bahasa: Sumantri B. Jakarta: Gramedia

Efendi, M. Mushonnif dan Purnomo, Jerry Dwi Trijoyo (2012) Analisis Faktor Konfirmatori untuk Mengetahui Kesadaran Berlalu Lintas Pengendara Sepeda Motor di Surabaya Timur, JURNAL SAINS DAN SENI ITS Vol. 1, No. 1, (Sept. 2012) ISSN: 2301-928X.

Hakim, L. (2014) Kebocoran Pendapatan Parkir di Surabaya Capai 40\%, Sindonews, http://daerah.sindonews.com/read/927971/23/kebocoran-pendapatan-parkir-di-surabaya-capai-40-1416720038, source: http://daerah.sindonews.com/read/927971/23/kebocoran-pendapatan-parkir-di-surabaya-capai-40-1416720038 retrieved in 15 th March 2015.

Hidayah, S., dan H. Widyastuti (2014) Studi Potensi Pendapatan dari Sektor On-Street Parking dan Off-Street Parking di Kabupaten Hulu Sungai Tengah, Tesis Bidang Studi Manajemen Rekayasa Tranportasi, Program Studi Pasca Sarjana, Jurusan Teknik Sipil, FTSP, Institut Teknologi Sepuluh Nopember Surabaya.

Hobbs F.D. (1984) Traffic planning and Engineering, Second edition Pergamon Press.

Kartika, A.A.G. dan A. Himawan (2013) Studi Pendapatan dari Sektor Parkir Jalan Umum Kota Surabaya, Seminar Nasional IX2013 Teknik Sipil ITS Surabaya, Peran Industri Konstruksi dalam Menunjang MP3EI (Masterplan Percepatan dan Perluasan Pembangunan Ekonomi Indonesia), Program Studi Pasca Sarjana, Jurusan Teknik Sipil, FTSP, Institut Teknologi Sepuluh Nopember Surabaya.

Khalid U.A. dan A.A.K. Hamsa (2013) Parking Utilization and Ride Facility at Public Transportation Terminals, Proceedings of the Eastern Asia Society for Transportation Studies, EASTS, Vol.9, 2013

Machsus dan Mukafi (2011) Kajian Kebutuhan Ruang Parkir pada Mall Galaxy di Kota Surabaya, Prosiding Seminar Nasional 
Aplikasi Teknologi Prasarana Wilayah (ATPW), 21 Juli 2011, ISBN: 978-979-18342-3-0. Program Studi Diploma Teknik Sipil, FTSP-ITS.

Mardiasmo (2009) Perpajakan, Penerbit ANDI, Yogyakarta.

Mantecchini L. (2015) Optimization of Airport Parking Facilities Size, Location and Construction, ARPN Journal Vol 10 No 2 February 2015

Mudjanarko S. W, H. Sulistio, L. Djakfar, and A. Wicaksono (2013) Behaviour Model of Motor Cycle User in Selecting Parking Location (Case study in Surabaya City of Indonesia), Journal of Basic Applied Sciencific Research, 3(7)842-846, 201.,

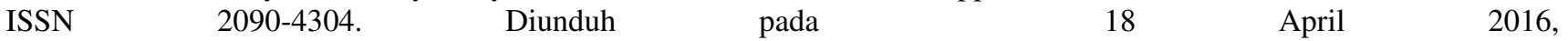
http://textroad.com/pdf/JBASR/J.\%20Basic.\%20Appl.\%20Sci.\%20Res.,\%203(7)842-846,\%202013.pdf.

Rizki M., CM Kosakoy dan TB Joewono (2014) Eksplorasi Kesediaan Membayar Parkir Mahasiswa Menggunakan Stated Preference Prosiding FSTPT 17, International Symposium, 22-24 August 2014, Universitas Jember Jawa Timur.

Renuka R and S. Dhanalakshmi (2015) Android-Based Smart Parking System Using Slot Allocation and Reservations, ARPN Journal of engineering and applied siences Vol 10, No 7, April 2015

Suarasurabaya.net (2015) Kelana Kota, DPRD Surabaya Soroti Kenaikan Tarif Parkir Mal. Retrieved from http://kelanakota.suarasurabaya.net/news/2015/148082-DPRD-Surabaya-Soroti-Kenaikan-Tarif-Parkir-Mal. Retrieved in 3rd March 2015.

Sutapa I K., P. A. Suthanaya, I W. Suweda (2008) Analisis Karakteristik dan Pemodelan Kebutuhan Parkir Pada Pusat Perbelanjaan di Kota Denpasar, Jurnal Ilmiah Teknik Sipil Vol. 12, No. 2, Juli 2008.

Thornton, J. F., M.D., Closson, Tom, B.A.Sc, M.B.A., Meagher, T., M.D., \& Johnsen, J. H., M.D. (2012). Hospital parking fees. Canadian Medical Association.Journal, 184(4), $\quad 439-40 . \quad$ Retrieved from http://search.proquest.com/docview/953522303?accountid=25704

Widhiastuti R., E. Priyadi dan Akhmadi (2013) Evaluasi dan Analisis Kebutuhan Ruang Parkir di Kampus Politeknik Negeri Pontianak, Jurnal Teknik Sipil Untan, Voume 13 No. 1, Juni 2013, Halaman 161-176.

Use the "Insert Citation" button to add citations to this document.

Peraturan Daerah Pemerintah Kota Surabaya No 1. Tahun 2009 tentang Penyelenggaraan Perparkiran dan Retribusi Parkir Kota Surabaya.

Peraturan Walikota Surabaya No. 36 Tahun 2015 Tentangg Perubahan Tarif Retribusi Pelayanan Parkir di Tepi Jalan. 